\title{
Proses Perubahan Arsitektural Kawasan Bersejarah Kampung WisATa KaUman SURAKaRTa
}

\author{
WIWIK SETYANINGSIH \\ JURUSAN ARSITEKTUR, FAKULTAS TEKNIK \\ UnIVERSITAS SEBELAS MARET, SURAKarTA \\ WIENDU NURYANTI \\ JURUSAN ARSITEKTUR, FAKULTAS TEKNIK \\ UNIVERSITAS GADJAH MADA, YOGYAKARTA \\ Budi Prayitno \\ JURUSAN ARSITEKTUR, FAKULTAS TEKNIK \\ UNIVERSITAS GADJAH MADA, YOGYAKARTA \\ AHMAD SARWADI \\ JURUSAN ARSITEKTUR, FAKULTAS TEKNIK \\ UNIVERSITAS GADJAH MADA, YOGYAKARTA
}

\begin{abstract}
Kawasan bersejarah dalam arsitektur perkotaan merupakan salah satu aset daya tarik wisata yang akan memberikan ikatan kesinambungan yang erat, antara masa lalu, masa kini dan masa mendatang.Kampung wisata, sebagai suatu kampung yang memiliki potensi keunikan fisik dan non fisik, yang dikelola secara terpadu dan terencana, sehingga siap untuk menerima kunjungan wisatawan. Selama ini eksistensi kawasan bersejarah yang memiliki kekentalan nilai sejarah belum ditangani dan dikelola secara optimal. Kecenderungan ini terlihat pada beberapa kawasan bersejarah yang telah kehilangan karakter aslinya, bahkan telah hilang dan berganti fungsi karena tidak terperhatikan. Maka salah satu penanganan awal adalah dengan merumuskan proses terjadinya perubahan arsitektural kawasan bersejarah kampung wisata. Tujuan penelitian ini, merumuskan perubahan arsitektural kawasan bersejarah kampung wisata Kauman.Rumusan didasarkan pada metode deskriptif eksploratif, pendekatan SWOT, dan mappingspasial fisik karakter kawasan, serta mapping sosekbud melalui FGD danPRA. Hasil akhir berupa rumusan perubahan arsitektural kawasan bersejarah kampung wisata Kauman, sebagai usulan Perda untuk direkomendasikan dan disosialisasikan secara networkinguntuk ditindaklanjuti oleh stakeholder terkait secara bersama.
\end{abstract}

Kata kunci : kawasan bersejarah, kampung wisata

\section{PENDAHULUAN}

Keberadaan kawasan bersejarah kampung Kauman sebagai kampung santri tradisional di tengah kota, awalnya merupakan area pemukiman yang diperuntukkan khusus bagi para Ulamapengelola Masjid Agung Karaton Kasunanan Surakarta dengan status tanah secara anggaduh yang berarti hanya berhak untuk menempati dan tidak punya hak untuk memiliki. Mereka mendapatkan gelar Kebangsawanan dari Karaton Kasunanan Surakarta.

Dengan adanya perubahan tatanan pemerintahan, maka Pangageng Karaton Kasunanan Surakarta memberikan perubahan status tanah anggaduh menjadi hak milik, dengan persyaratan tertentu kepada beberapa pengelola

Masjid Agung yang memenuhi
persyaratan.
Dengan adanya proses pertumbuhan dan perkembangan kota Surakarta yang pesat, hal ini membawa pengaruh pergeseran dan pembaharuan pada permukiman tradisional yang ada di pusat kota dan lingkungan sekitarnya. Pada tahun 2000, Pemda Surakarta berhasil menciptakan branding Kota Surakarta Kota Budaya dan Pariwisata yang dikenal hingga tingkat internasional. Kemudian tahun 2006, menyusul pencanangan branding kampung Kauman dibuka oleh Pemkot Surakarta menjadi kawasan wisata religius, budaya dan batik. Hal ini menciptakan sebuah identitas baru bagi kawasan bersejarah kampung Kauman 
yakni dari area pemukiman menjadi area wisata.

Perubahan identitas/citra Kampung memberikan banyak perubahan pada pola tata bangunan dan lingkungan. Perubahan identitas juga menimbulkan semakin banyaknya area komersial pada kampung yang tidak memiliki susunan penzoningan yang jelas atau tumbuh dengan sendirinya. Hal ini menimbulkan percampuran zona hunian dan non hunian (mix- use), serta penumpukan sirkulasi public-privat pada kawasan bersejarah kampung Kauman. Perubahan tersebut tidak lagi mencerminkan potensi karakter kampung santri tradisional yang bersejarah pada kawasan kampung Kauman.

\section{IMETODE PENELITIAN}

Penelitian ini dilakukan secara terpadu, bertujuan merumuskan perubahan arsitektural kawasan bersejarah kampung wisata Kauman Surakarta.

Rumusan didasarkan pada metode deskriptif eksploratif, pendekatan SWOT, dan mappingspasial fisik karakter kawasan, serta mapping sosekbud.

Lokasi penelitian adalah kawasan bersejarah kampung wisata kauman surakarta dengan potensi karakteristik kearifan lokal yang tinggi, serta kegiatan di dalamnya masih eksis dan berkembang. Hasil akhir berupa rumusan perubahan arsitektural kawasan bersejarah kampung wisata Kauman Surakarta, sebagai usulan Perda untuk direkomendasikan dan disosialisasikan secara networkinguntuk ditindaklanjuti oleh stakeholder terkait secara bersama.

\section{HASIL DAN PEIMBAHASAN \\ Pola Tata Ruang, Bangunan dan Lingkungan KampungKauman \\ Keberadaan kawasan bersejarah} kampung Kauman Surakarta merupakan salah satu kelengkapan bangunan Masjid Agung sebagai pusat syiar agama Islam, serta berdirinya Karaton Kasunanan Surakarta oleh $P B$ II, pada 17 Pebruari tahun 1745 H. Sekitar tahun 1757 M, kawasan bersejarah kampung Kauman merupakan sebuah lahan milik Karaton
Kasunanan Surakarta yang difungsikan sebagai area pemukiman bagi para Ulama Karaton beserta santri-santrinya yang bertugas mengelola Masjid Agung secara hanggaduh, hanya berhak menempati, tidak berhak untuk memiliki. Para Ulama tersebut mendapatkan gelar Kebangsawanan dari Karaton Kasunanan Surakarta sebagai Ulama Abdi Dalem.

Dengan adanya pergeseran pemerintahan, pada masa PB X (1911), terjadi reorganisasi tanah Karaton disebut Kompleks. $\mathrm{Hal}$ ini mengakibatkan munculnya perubahan fundamental tentang pola kepemilikan dan penguasaan atas tanah Karaton Kasunanan Surakarta, dari tanah milik Karaton yang di bagikan kepada Ulama Abdi Dalemdari status hanggaduh, di alihkan menjadi tanah hak milik. Salah satu syaratnya adalah bagi Ulama Abdi Dalemdan kawula dalemyang telah menjadi pengelola, penggarap maupunpenunggu selama sekian-tahun.

Ditambahkan lagi bahwa, pada masa pemerintahan PB X sampai dengan tahun 1960-an, etnis Cina yang menghuni kawasan bersejarah kampung Kauman diatur menurut hukum adat, yaitu etnis Cina hanya boleh menempati untuk tempat tinggal hanya pada lapis pertama dari jalan utama (W. Setyaningsih, 2000). Selanjutnya sejalan dengan perubahan tatanan pemerintahan dan perkembangan yang terjadi, atas kesepakatan penduduk asli dan peninjauan kembali hukum adat, maka etnis Cina diberi sedikit kelonggaran untuk dapat menempati sebagai tempat tinggal sampai pada lapis ke dua dari jalan utama (maximum 80meter masuk ke dalam). Walaupun demikian sampai sekarang etnis Cina cenderung tidak banyak yang menempati kawasan pada lapis kedua. (Gambar.l dapat dilihat pada lampirandi halaman 7)

Pada awalnya, permukiman kawasan bersejarah kampung Kauman berstatus anggaduh yang cenderung memberikan keseragaman dalam bentuk dan tatanan massa bangunannya. Pola permukiman berorientasi utama pada Masjid Agung yang merupakan pusat penyebaran aktivitas masyarakat dan landmark Kauman. Kegiatan pada tiap unit 
lingkungan berorientasi pada langgar yang tersebar di Kauman. Langgarlanggar tersebut berorientasi ke arah kiblat/ka'bah/barat sehingga arah hadap dan arah jalan masuk menyesuaikan dengan jalan lingkungan yang ada.

Permukiman Kauman terbagi menjadi dua bagian, yaitu bagian tengah/dalam dan bagian luar yang bersinggungan dengan jalan arteri. Mayoritas penduduk pada Kauman bagian tengah/dalam merupakan para Kyai/Ulama dan garis keturunannya cenderung suku Jawa. Permukiman ini memiliki toponim nama tempat berdasarkan jenis pekerjaan dan keahlian masyarakatnya, yaitu:

Kampung Pengulon: tempat tinggal/ dalem Penghulu Karaton; Kampung Sememen: tempat tinggal/rumah Ketib Sememi dan Langgar Sememen; Kampung Modinan: tempat tinggal para Modin; Kampung Baladan:tempat aktivitas kawulo dalem, membuat makanan sesaji Keraton; Kampung Blodiran: Tempat aktivitas kawulo dalem, menjahit dan membordir; Kampung Gebangsan : tempat aktivitas kawulo dalem dalam membuat kuluk/topi (biasa digunakan masyarakat muslim untuk sholat) .

Selanjutnya semakin banyak teteko yang bermukim di kawasan bersejarah kampung Kauman yang bekerja sebagai kawulo dalem untuk memenuhi kebutuhan Karaton. Beberapa diantaranya bekerja sebagai tukang jahit/bordir di kampung Blodiran, sebagai pembuat kuluk di kampung Gebangsan. Adapun nama-nama kampung di kawasan bersejarah kampung Kauman merupakan toponim dari nama-nama Ketib/Ulama yang menempati bekas tanah hanggaduh yang telah berubah menjadi hak milik, serta toponim dari nama dan jenis kegiatan masyarakat teteko yang berada di dalamnya.

Sejalan dengan pertumbuhan kota, maka terjadi pergeseran spasial baik fisik maupun non fisik, khususnya pada daerah pinggiran banyak digunakan penduduk asli maupun pendatang sebagai area pertokoan dan perdagangan. Mulai tahun 1988, sejak diterbitkannya Kepres No.23, tentang pengalihan kekuasaan dari Karaton Kasunanan Surakarta ke pemerintah, pengaruh kehidupan Karaton sudah tidak erat lagi, bahkan masyarakat kawasan bersejarah kampung Kauman sudah jarang yang menggunakan gelar kebangsawanannya. Walaupun demikian hubungan kekerabatan masih terlihat erat tidak ada perubahan yang berarti.

Struktur masyarakat dikawasan bersejarah kampung Kauman awalnya dibedakan menjadi kelompok priyayi/ bangsawan dan kawulo dalem/rakyat biasa dimana strata sosial-ekonominya lebih rendah. Pada tahun 1942 terjadi pengambilalihan pemerintahan Karaton Kasunanan Surakarta oleh pihak pemerintahan Jepang, menyebabkan gaji para Ulama Abdi Dalem berkurang. Atas inisiatif pihak Karaton, untuk tetap menjaga privacy dan ke eksissan para Ulama Abdi Dalem Karaton Kasunanan Surakarta, maka awalnya para garwo/istri Ketib/Ulamatersebut dibudayakan membuat salah satu tradisi pusaka Karaton Kasunanan Surakarta adalah membuat karya kerajinan/ketrampilankain batik sebagai home-industrykhusus untuk kebutuhan privacy Karaton saja (tidak diperjual belikan).

Hal ini menjadi daya tarik kaum pendatang/teteko untuk bermukim di kawasan bersejarah kampung Kauman. Mereka kemudian bekerja sebagai Kawulo Dalem untuk memenuhi kebutuhan Karaton.Seiring perkembangan jaman dan meningkatnya kebutuhan ekonomi yang semakin mendesak, selanjutnya oleh para teteko kerajinan kain batik tadi dibuat sendiri, untuk di perdagangkan keluar dari Karaton sebagai penambah penghasilan keluarga.

Para tetekoikut berperan serta dalam perdagangan kain batik, yakni sebagai saudagar/pengusaha batik (Setyaningsih, W, 2010). Perubahan status dan aktivitas masyarakat inilah yang menyebabkan pudarnya karakter asli kawasan bersejarah kampung Kauman sebagai permukiman santri di pusat kota menjadi cenderung menonjolkan karakter 
komersial bisnis. Hal ini menjadi awal terjadinya proses perubahan fungsi dan karakter kawasan bersejarah kampung Kauman.

\section{Perubahan Arsitektural Kawasan Bersejarah Kampung Wisata Kauman}

Berdasarkan observasi di lapangan, dapat disimpulkan bahwa terdapat kecenderungan beberapa bangunan hunian yang berubah menjadi non hunian terutama yang berbatasan dengan jalan arteri, aksis utama dan jalan lingkungan di kawasan bersejarah kampung Kauman.

Diawali dengan adanya perubahan status pemerintahan dari Karaton Kasunanan Surakarta ke Pemerintah Surakarta, terjadi perubahan status anggaduhdari para Ketib/Ulama Abdi Dalemmenjadi berstatus kepemilikan sendiri,sehingga mengakibatkan pemilik rumah cenderung bebas mengubah dan menentukan pola tatanan dan karakter bangunannya. Hal ini menyebabkan terjadinya perubahan-perubahan yang berakibat munculnya keragaman dalam fungsi dan karakter bangunan di kawasan bersejarah kampung Kauman.

Fenomena-fenomena tersebut di atas menciptakan keragaman pada lingkungan di kawasan bersejarah Kauman. Perubahan fungsi bangunan juga mengakibatkan semakin sedikitnya jumlah bangunan kuno rumah Ketib/Ulamayang masih berdiri di mana bangunan kuno rumah Ketib/Ulama merupakan salah satu bukti yang menunjukkan karakter asli kawasan bersejarah kampung Kauman. Semakin sedikitnya bangunan kuno tersebut maka akan semakin memperkuat kepudaran identitas kawasan bersejarah kampung Kauman sebagai pemukiman santri.

Seiring adanya perkembangan jaman dan pemerintahan, dengan munculnya berbagai fenomena yang ada, maka hal ini menyebabkan adanya percampuran (mix use) fungsi kawasan, adanya perubahan fungsi bangunan di kawasan bersejarah Kauman dari permukiman (hunian) para Ketib/Ulama Abdi Dalem menjadi bangunan komersial showroom batik (non-hunian). Perubahan status dan aktivitas penduduk menyebabkan pudarnya karakter asli kawasan bersejarah kampung Kauman sebagai permukiman santri di pusat kota menjadi cenderung menonjolkan karakter komersial bisnis. Hal ini menjadi awal terjadinya proses perubahan fungsi dan tampilan karakterkawasan Kauman.

Hal ini mengakibatkan percampuran antara zona hunian-non hunian dan penumpukan sirkulasi privat-publik terutama pada bagian dalam/tengah kawasan bersejarah kampung Kauman. Bangunan pada bagian luar Kauman telah didominasi oleh fungsi ruko, pertokoan dan perkantoran. Perbedaan kondisi ini mengakibatkan perbedaan fungsi dan karakter kawasan bersejarah kampung Kauman. Selanjutnya Kauman berkembang menjadi kawasan yang khas dengan penghuni beragam. Secara garis besar ada tiga jenis karakter bangunan rumah bersejarah di Kauman, yaitu 1). rumah Ketib/Khotib; 2). rumah Jawa; dan 3). rumah Barat yang dipengaruhi budaya Jawa.

Fenomena adanya perubahan tersebut diresmikan oleh Pemerintah Kota Surakarta pada tahun 2006 dalam usahanya membangun dan mengembangkan dengan menggulirkan Kampung Wisata Kauman. Namun perubahan fungsi yang terjadi tersebut tidak dibatasi dengan peraturan yang jelas dan tegas dalam hal tata ruang, bangunan dan lingkungan, serta dalam hal pemeliharaan bangunan kuno rumah Ketib/Ulama sebagai cagar budaya.

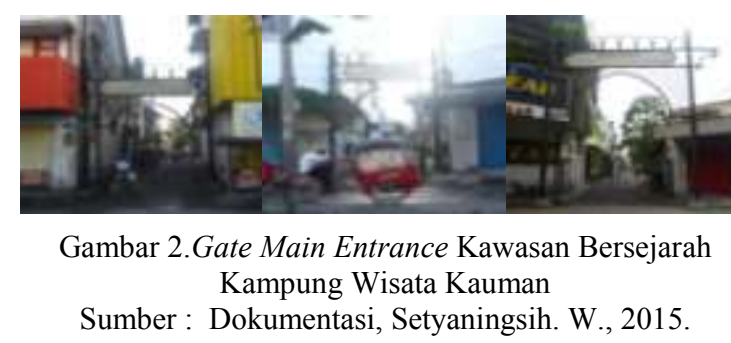

Tidak adanya batasan penzoningan, tatanan dan perubahan status anggaduh menjadi kepemilikan sendiri mengakibatkan terjadinya percampuran zona hunian-non hunian yang mengakibatkan keragaman pada pola tatanan massa dan ruang Kauman. Perubahan pada bangunan diantaranya pada perubahan fungsi, bentuk tampilan 
muka fasade bangunan, serta elemen material bangunan. Sedangkan perubahan pada lingkungan diantaranya perubahan area terbuka, parkir, serta perubahan pada akses sirkulasi jalan. Keragaman tersebut cenderung menghilangkan karakter di kawasan bersejarah Kauman.

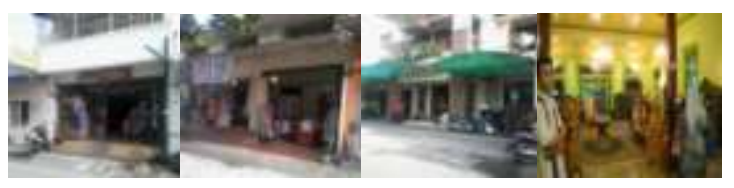

Gambar 3.Keragaman Fungsi dan Fasade Bangunan

Komersialdi Kawasan Bersejarah Kampung Wisata Kauman

Sumber : Dokumentasi, Setyaningsih. W., 2015.

Namun demikian dengan keragaman secara visual tersebut justru cenderung menjadikan kawasan bersejarah kampung Kauman lebih dinamis dan ramah sebagai kampung wisata, hal tersebut telah menciptakan berbagai pembaharuan dalam berbagai hal. Diantaranya adalah meningkatnya keindahan suasana kampung tersebut menjadi lebih terlihat tertata nyaman dan aman untuk dikunjungi. Sehingga hal ini meninbulkan dampak ekonomi yang ditimbulkan oleh kegiatan pariwisata, dan akan meningkatkan kesejahteraan masyarakat lokal.

Dengan adanya pembangunan citywalkdi bagian selatan Jalan Slamet Riyadi serta fasilitas street furniture, maka hal ini semakin memperkuat keberadaan kawasan bersejarah kampung Kauman. Ditambahkan pada tahun 2010 Pemkot Surakarta menggulirkan kawasan bersejarah kampung Kauman sebagai kawasan Strategis. Fenomena tersebut mengakibatkan semakin berkurangnya fungsi permukiman (hunian) yang digantikan dengan bangunan publik yang bersifat komersial/bisnis (nonhunian/mix-use), cenderung berganti sebagai showroom-batik. $\mathrm{Hal}$ ini cenderung mengubah fungsi dan karakterlingkungan kawasan bersejarah kampung Kauman menjadi kawasan komersial Kampung Wisata Kauman sebagai kawasan Wisata Religi, Wisata Budaya dan Wisata Belanja (W. Setyaningsih, 2009; 2010).
Seiring dengan perkembangan jaman, dengan adanya kawasan komersial showroom-batikpada kawasan bersejarah kampung Kauman semakin banyak bermunculan dimana hal ini meningkatkan taraf hidup masyarakat asli. Hal tersebut terjadi karena pembangunan pada kawasan bersejarah kampung Kauman tidak diiringi dengan perencanaan yang matang melainkan tumbuh dengan sendirinya, bahkan terjadi penghancuran bangunan kuno, dikarenakan kampung ini belum mendapatkan perlindungan dari hukum cagar budaya. Hal ini menyebabkan tidakterlindunginya dan semakin berkurangnya keberadaan bangunan kuno bersejarah pada kawasan bersejarah kampung Kauman.

\section{KESIMPULAN}

Proses perubahan arsitektural kawasan bersejarahkampung Kauman Surakarta, diawali dengan adanya pergantian sistem pemerintah perubahan status tanah dan bangunan dari anggaduh menjadi kepemilikan sendiri. Hal ini sebagai penyebab dari faktor internal yang merubah fungsi bangunan dan tampilan muka fasade karakterbangunan dan lingkungan kawasan bersejarah kampung Kauman.

Ditambahkan adanya faktor-faktor eksternal dari pemerintah, dengan adanya pembangunan fisik sebagai pendukung keberadaan Kampung Wisata Kaumanyang mengakibatkan perubahan fungsi bangunan kawasan dan karakterlingkungan kawasan bersejarah kampung Kauman menjadi kawasan wisata atau bisnis (komersial).

$\mathrm{Hal}$ ini semakin memotivasi masyarakat untuk berperan serta dalam memepercepat terjadinya proses perubahan kawasan bersejarah kampung Kauman menjadi Kawasan Wisata Kauman yang berdampak positip pada perekonomian masyarakat lokal khususnya..

\section{DAFTAR PUSTAKA}

Asworth, G.j., Tunbridge, J.E. 1990. The Tourist-Historic City. Belhaven Press. London and New York. 
Bramwell, B. 1994. Rural Tourism and Sustainable Rural Tourism. Dalam B. Bramwell \& B. Lane. Rural Tourism and Sustainable Rural Development. Clevedon, Ireland: Channel View Publication, Hal. 16.

Cooper, C, 2005, Tourism Principle and Practice, Pearson Education.

Gannon, A. 1994. Rural Tourism as a Factor in Rural Community Economic Development for Economic in Transition. Dalam B. Bramwell \& B. Lane. Rural Tourism and Sustainable Rural Development. Clevedon, Ireland: Channel View Publication, Hal. 77-92.

Inskeep, E. 1991. Tourism Planning: An Integrated and Sustainable Development Approach. New York: Van Nostrand Reinhold.

Lane, B. 1994. Sustainable Rural Tourism Strategies: A Tool for Development and Conservation. Journal of Sustainable Tourism, 2(1), 102111.

Nuryanti, W. 1999. Cultural Tourism in Yogyakarta: Cultural, Heritage, and Development, Pp. 153-159 On Monuments And Sites Indonesia, ICOSMOS Scientific Publication.

Sullivan, 1980, Back Alley Neighbourhood: Kampung as Urban Community in Yogyakarta. Melbourne, Centre of Southeat Asian Studies, Monas University.

Timothy, D.J., Boyd, S.W. 2003. Heritage Tourism, Themes in Tourism, Prentice Hall, Pp. 276-280

Tosun. C. 2000. Limits to Community Participation in the Tourism Development Process in Developing Countries, Tourism Management, (2000) 613-633.

Wearing, S, 2002, The development of Community-based Tourism: Rethinking the Relationship between Tour Operators and Development Agents as Intermediaries in Rural and Isolated Area Communities, Journal of Sustainable Tourism.

Wiwik, S. 2013. The Kauman Settlement in Surakarta and the Typology of the Rumah Ketib on Insular Diversity
Architecture Culture Identity in Indonesia. Published by Institute for Comparative Research in Architecture IVA-ICRA, Vienna, Austria 2013 and Department of Architecture and Planning Faculty of Engineering, Gadjah Mada University Yogyakarta, Indonesia. ISBN 978-3-900265-16-4

Wiwik, S. 2012.Proceeding:The Historic Area Conservation Toward Heritage Tourism In Kauman Settlemet Surakarta, Proceeding In International Conference On Indonesian Architecture And Planning, ICIAP. UGM, Yogyakarta, 9 - 10 July, 2012. ISBN 978-979-98815-5-7.

Wiwik, S. 201 l.Typology of Rumah Ketib toward Cultural Heritage Tourism of Local Wisdom in Kauman Surakarta. Proceeding of International Seminar on " Exploring Noble Values of Local Wisdom and Prime Javanese Culture to Strengthen the Nation Identity" \&The Declaration of the Institute of Javanologi LPPM Sebelas Maret University, UNS Surakarta, March, $6-7^{\text {th }}, 2011$. ISBN 978-979-498-617-2.

Wiwik, S. 2010.Model Pengembangan Kampung Wisata yang Berbasis pada Peran dan Interpretasi Masyarakat sebagai Alternatip Peningkatan Ekonomi Kreatip dalam Pengembangan Destinasi Pariwisata Kampung Ulama Kauman Surakarta, Hibah Stranas. No. Kontrak :172/SP2H/PP/DP2M/III/2010, 1 Maret 2010

Wiwik, S. 2009.Model Pelestarian Kawasan Bersejarah Melalui Peningkatan Peran dan Interpretasi Masyarakat Sebagai Alternatip Pengembangan Wisata Budaya Yang Berkelanjutan, Stranas. No. Kontrak 017/SP2H/DP2M/PP/VI/2009, 16 Juni 2009.

Wiwik, S. 2000. Sistem Spasial Rumah Ketib di Kauman Surakarta, Thesis S2 Universitas Gadjah Mada, Yogyakarta, Indonesia. 


\section{LAMPIRAN}

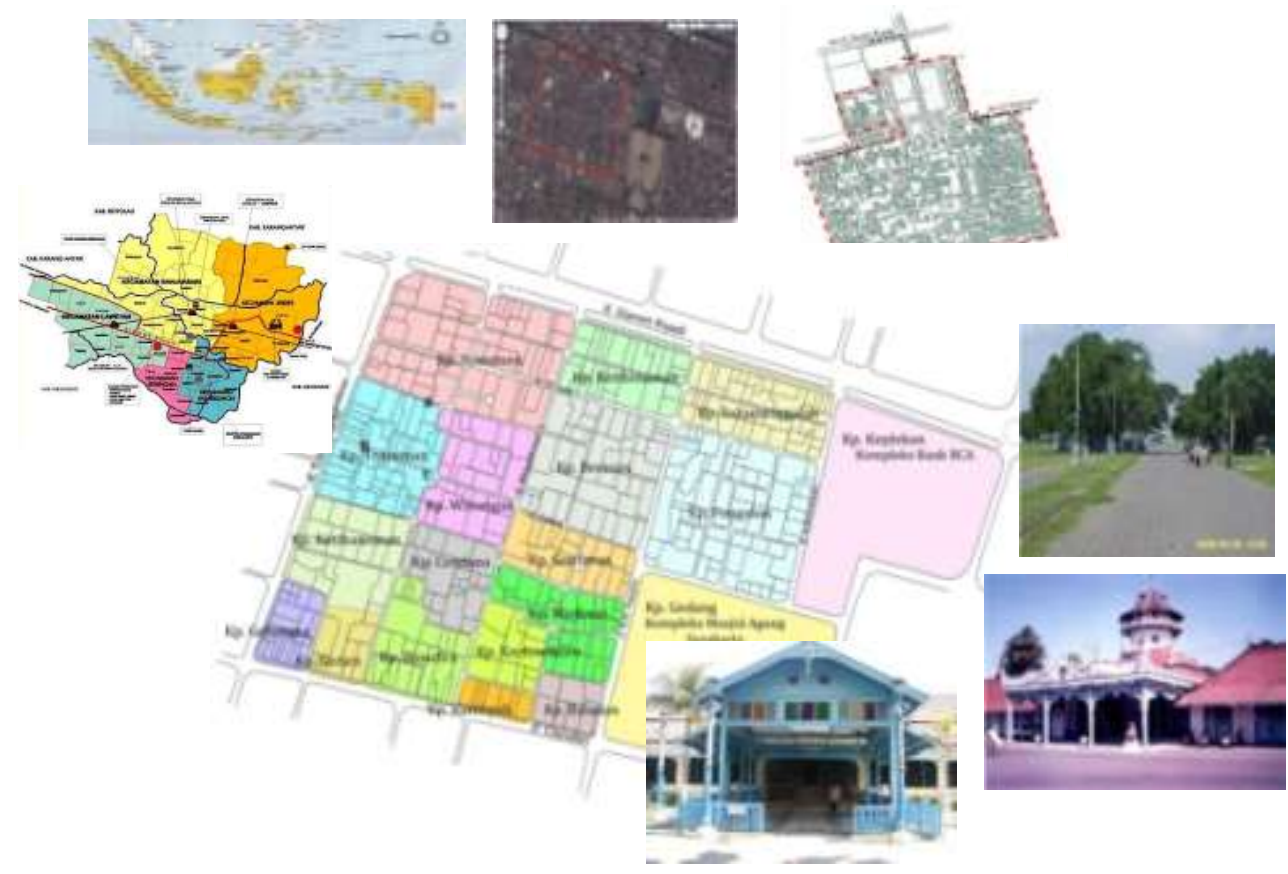

\begin{tabular}{|l|l|l|l|}
\hline Kmp. Gedang & Kmp. Trayeman & Kmp. & Kmp. Baladan \\
Selirang & Kmp. Winongan & Sutomenggalan & Kmp. Blodiran \\
Kmp. Pengulon & Kmp. & Kmp. Keplekan & Kmp. Kintiran \\
Kmp. Modiman & Ketibanoman & Kmp. Berasan & Kmp. Gerjen \\
Kmp. Ketibimanan & Kmp. Cendanan & Kmp. Kertowikaran & Kmp. \\
Kmp
\end{tabular}

Gambar 1.Profil Kampung Wisata Batik Kauman Sumber : Analisis, Setyaningsih. W., 2015. 